\title{
Preliminary Study of The Nutritional Content and Phytochemical Constituent of An Under-Utilised Bitter Melon Plant
}

\author{
*JIMAH, A., ODION-OWASE, E. AND SULEIMAN, M. \\ Department of Food Technology, Auchi Polytechnic Auchi
}

\begin{abstract}
Bitter melon (momordica charantia) plant is used for some medicinal purposes in traditional medicine but the food value was investigated. The nutritional compositions and phytochemical constituents of the powdered leaf and fruit were investigated using standard analytical methods. The proximate compositions showed the percentage of moisture content $(11.38 \pm 0.29$ and $10.74 \pm 0.02)$, ash $(14.39 \pm 0.02$ and $7.40 \pm 0.1)$, crude fat $(2.65 \pm 0.10$ and 6.11 $\pm 0.05)$, crude fibre $(16.11 \pm 0.04$ and $13.61 \pm 0.04)$, crude protein $(21.19 \pm 0.52$ and $27.92 \pm 0.06)$, and carbohydrate (33.94 \pm 0.25 and $34.22 \pm 0.11$ ) of samples on a dry weight basis for the leaf and the fruit respectively. Also, the mineral analysis showed the concentration in $\mathrm{mg} / 100 \mathrm{~g}$ of $\mathrm{Ca}(239.65 \pm 0.30$ and $70.60 \pm 0.23), \mathrm{Na}(40.40 \pm 0.04$ and $23.47 \pm 0.02), \mathrm{K}(67.22 \pm 0.02$ and $319.25 \pm 0.03)$, Fe $(4.98 \pm 0.02$ and $5.64 \pm 0.04), \mathrm{Zn}(24.5 \pm 0.40$ and 17.40 $\pm 0.56)$ and $\mathrm{Cu}(4.96 \pm 0.20$ and $2.57 \pm 0.06)$ of samples on a dry weight basis for the leaf and fruit respectively. Powdered samples of the leaves were extracted with water and ethanol respectively to isolate the required phytochemicals. Phytochemicals like phytate, alkaloids, tannins, saponins, and oxalate were found present in appreciable level except for the glycoside which is present in trace amount in the water extract. The study indicates the presence of nutritional components that are beneficial in addition to the purported numerous medicinal values of the plant.
\end{abstract}

Keywords: Momordica, bitter melon, proximate composition, minerals, phytochemicals.

DOI: $10.7176 /$ JNSR12-2-03

Publication date: January $31^{\text {st }} 2021$

\section{Introduction}

Bitter melon/gourd (Momordica charantia) is a tropical and subtropical vine of the family Cucurbitaceae has widely grown in India, South Asia, China, Africa and the Caribbean. Bitter melon as fondly called has been implicated experimentally to achieve a positive sugar regulatory effect by suppressing the neural response to sweet taste stimuli and also keep the body functions operating normally (Sofowora, 2006). The Yoruba people of Nigeria popularly call it ejinrin. Igbo-kakayi and Hausa-gàraàfúnií (Egbon et al., 2015). Bitter gourd is very bitter in taste and dark green in colour; hence it is not consumed widely for the table purpose. The characteristic bitter taste of bitter gourd is due to the bitter principle 'momordicin'. The excellent nutritive and therapeutic value of this fruit offers great potential for processing of quality products (Deepa, 2015).

Deepa, 2015 also reported that the nutrient composition of bitter gourd was moisture $92.4 \mathrm{~g}$, Protein $1.6 \mathrm{~g}$, fat $1 \mathrm{~g}$, ash $0.8 \mathrm{~g}$, crude fibre $0.8 \mathrm{~g}$, carbohydrate $4.2 \mathrm{~g}$, energy $25 \mathrm{kcal}$, calcium $20 \mathrm{mg}$, iron $0.61 \mathrm{mg}$, sodium $2.4 \mathrm{mg}$, potassium $171 \mathrm{mg}$ and zinc $0.39 \mathrm{mg} / 100 \mathrm{~g}$.

The fruits of bitter gourd are very much consumed as fresh and as a dried vegetable for curries, bakery products, pickled or stuffed products of meat. It is also used for the preparation of several dishes. It can be fried, deep-fried, boiled, pickled, juiced, and dried to drink as tea (Myojin et al., 2008). Bitter melon is rich in iron and has twice the beta carotene of broccoli, twice the calcium of spinach, twice the potassium of bananas, and contains vitamins B1 to 3, C and good dietary fibre. It is believed to contain insulin. The main constituents include steroidal saponins known as charantin, insulin-like peptides and alkaloids (Anonymous, 2020).

Recently, several phytochemicals with the health benefits of bitter gourd have been isolated and studied (Murakami et al., 2001). Charantins, a mixture of steroidal saponins that are abundant in the fruit of bitter gourd, has been proposed to contribute to the hypoglycemic and antihyperglycemic activity of bitter gourd (Harinantenaina et al., 2006). Additionally, bitter gourd is a good source of phenolic compounds, including gallic acid, gentisic acid (2, 5-dihydroxyl benzoic acid), catechins, chlorogenic acid and epicatechin (Ahmad et al., 2011).

Other uses of the plant include is to expel intestinal gas, for tumours, wound treatment, rheumatism, malaria, vaginal discharge (Sofowora, 2006). A tea prepared from the leaf is used for diabetes in Nigeria, Ghana and India peninsula (Egbon et al, 2015) The young fruits and shoots are reported to serve as supplementary or emergency food in some part of West Africa, and it is a popular food throughout southern Asia, India, China, Pakistan, Bangladesh, Vietnam, Philippines, Nepal, and Trinidad and Tobago (Bagchi, 2005).

Despite having amazing health benefits, bitter gourd is not consumed. Till now there is no such data available about the nutrient content of the bitter melon used in Nigeria despite being popularly used in traditional medicine especially in the western part of the country. Very little attention has been given for the development of bitter gourd products in Nigeria and the literature available on this aspect is meagre (Egbon and Jimah, 2015). Therefore, the prevailing situation is provoking us to analyze the bioactive plant, the bitter melon. This preliminary study has 
been undertaken to obtain information regarding the proximate composition, mineral content as well as the biologically important phytochemicals of bitter gourd.

\section{Method of Collection of Plant Materials}

Fresh leaf and fruit of the herbs were harvested between June and July 2019, in Auchi, Edo State, Nigeria. They were identified and authenticated by the Department of Botany, Ambrose Alli University Ekpoma, and Nigeria. The plant materials were sorted out to eliminate all extraneous materials. The samples were washed with the deionised water to remove dust particles.

\section{Processing of Powder Samples}

Blanching: The sliced samples were blanched in hot water with 5 per cent sodium chloride at $100{ }^{\circ} \mathrm{C}$ for three minutes to remove bitterness and maintaining the firmness of the bitter gourd slices.

Dehydration: Bitter gourd sample was drained, cut into small pieces and dried in a hot air oven at $60^{\circ} \mathrm{C}$ for $8-10$ hours (Odetola and Akojenu, 2000).

Grinding: After drying, the dehydrated bitter gourd was ground into a fine powder using an electric blender, and then passed through a $60 \mathrm{~mm}$ mesh sieve to get a fine powder. $100 \mathrm{~g}$ of the powdered sample each were stored in airtight containers and kept under normal room temperature until required.

\section{Proximate Analysis}

The proximate analysis was carried out according to the procedure of Association of Official Analytical Chemist (AOAC, 2000) Moisture content (AOAC 934.01) was determined by evaporation by heat using drying oven at $100^{\circ} \mathrm{C}$, Crude Fat Content (AOAC 920.39) was determined using solvent extraction (soxhlet) method, Crude Protein Content (AOAC 955.04) by Kjeldahl method, Crude Fibre Content (AOAC 962.09) by Gravimetric method and carbohydrate by difference according to Ihekoronye and Ngoddy, 1985.

\section{Mineral Analysis:}

The elements were analysed using Atomic Absorption Spectrophotometer and Flame Photometer. The Atomic Absorption Spectrophotometer (AAS) was used to analyse $\mathrm{Cu}, \mathrm{Fe}$ and $\mathrm{Zn}$ while the Flame Photometer was used to analysed for $\mathrm{Na}, \mathrm{P}, \mathrm{K}, \mathrm{Ca}$ and $\mathrm{Mg}$ and each mineral element with their appropriate hollow cathode lamp. The experiments were done in triplicate and the results were averaged (Bakare, et al., 2010).

\section{Phytochemical Screening}

The analysis for tannin, saponin, phytate, glycoside, oxalate and alkaloids were carried out according to standard methods, (Sofowara, 1993).

\section{Statistical Analysis}

Each experiment was repeated three times. All obtained were subjected to analysis of variance. Simple means were reported using Duncan's Multiple Range test $(\mathrm{P} \leq 0.05)$. Results were then presented as mean \pm standard deviation (SD). This was done with Statistical Packages for Social Sciences (SPSS version 20.0).

\section{Results}

Table 1: Proximate composition of bitter melon leaf and fruit powders

\begin{tabular}{llc}
\hline Parameter & \multicolumn{2}{c}{ \% composition } \\
\cline { 2 - 3 } & Leaf & Fruit \\
\hline Moisture (WW) & $82.83 \pm 0.21$ & $90.84 \pm 0.17$ \\
Moisture (DW) & $11.38 \pm 0.29$ & $10.74 \pm 0.02$ \\
Total ash (DW) & $14.39 \pm 0.02$ & $7.40 \pm 0.10$ \\
Crude fat (DW) & $2.65 \pm 0.10$ & $6.11 \pm 0.05$ \\
Crude fibre (DW) & $16.11 \pm 0.04$ & $13.61 \pm 0.04$ \\
Crude protein (DW) & $21.19 \pm 0.52$ & $27.92 \pm 0.06$ \\
Carbohydrate (DW) & $33.94 \pm 0.25$ & $34.22 \pm 0.11$ \\
Results are mean of 3 determinations $\pm \mathrm{SD} ; \mathrm{DW}=$ Dry weight \& WW $=$ Wet weight \\
\hline
\end{tabular}


Table 2: Mineral composition of bitter melon leaf and fruit powders

\begin{tabular}{lll}
\hline Minerals & \multicolumn{2}{c}{ Concentration $\mathbf{( m g / 1 0 0 g )}$} \\
\cline { 2 - 3 } & \multicolumn{1}{c}{ Leaf } & Fruit \\
\hline Calcium & $239.65 \pm 0.30$ & $70.60 \pm 0.23$ \\
Sodium & $40.40 \pm 0.04$ & $23.47 \pm 0.02$ \\
Potassium & $67.22 \pm 0.02$ & $319.25 \pm 0.03$ \\
Iron & $4.98 \pm 0.02$ & $5.64 \pm 0.04$ \\
Zinc & $24.5 \pm 0.40$ & $17.40 \pm 0.56$ \\
Copper & $4.96 \pm 0.20$ & $2.57 \pm 0.06$ \\
Results are mean of 3 determinations \pm SD; & \\
\hline
\end{tabular}

Table 3: Phytochemical screening of bitter melon leaf powder

\begin{tabular}{|c|c|c|}
\hline Phytochemicals & Water extract & Ethanol extract \\
\hline Phytate & ++ & +++ \\
\hline Tannin & +++ & +++ \\
\hline Oxalate & ++ & ++ \\
\hline Saponin & +++ & + \\
\hline Alkaloid & + & ++ \\
\hline Glycoside & + & - \\
\hline
\end{tabular}

\section{Discussion}

In table 1 , the dry weight basis of the powders of the leaf and fruit compositions that are $11.38 \%$ and $10.74 \%$ respectively expressed the optimal function of all the nutrients because they are all present in adequate amount. The fruit of mormordica charantia has a higher percentage of the protein content of $27.92 \%$ when compared to the leaf of $21.19 \%$ respectively. The result obtained can also be compared favourably to protein-rich foods like soybeans, cowpeas, melon and pumpkin $(23.10 \%-33.00 \%)$. The crude fat content in Momordica charantia fruit $(6.11 \%)$ was higher than that of the leaf $(2.65 \%)$. The crude fat may add to the caloric value extractable from the fruit for metabolic activities. Though the crude fibre, total ash and the moisture content are higher in the leaf sample $(16.11 \%, 14.39 \%$ and $11.38 \%)$ as compare to the fruit sample $(13.61 \%, 7.40 \%$ and $10.74 \%)$ respectively. The study also shows that the plant contains a reasonable amount of fibre which could be beneficial when consumed. Dietary fibre is important for lowering blood cholesterol and blood sugar. It is known to reduce the risk of diseases such as obesity, diabetes, breast cancer, hypertension and gastrointestinal disorder. (Bakare et al, 2010)

In table 2, the ash content represents all the elements present in the sample. The study shows that the minerals are more concentrated in the leaf than in the fruit except for the potassium. The elements such as calcium, potassium, zinc, iron, copper, and sodium which were found in a reasonable amount in the leaf and the fruit as expressed in $\mathrm{mg} / 100 \mathrm{~g}$ in table 2 . They are nutritionally and biochemically important for proper body function. For instance, calcium is known to play a significant role in muscle contraction, bone and teeth formation and blood clotting. Zinc is needed as a cofactor in enzyme catalysis in the body. Sodium and potassium which are present in the intracellular and extracellular fluid help to maintain electrolyte balance and membrane fluidity. Iron is known to be a component of some metalloenzymes, myoglobin and haemoglobin, which is needed in the transport of oxygen and carbon dioxide during respiration or cellular metabolism. This haemoglobin (containing iron) also serves as a buffer to regulate changes in blood $\mathrm{pH}$. It is known that inorganic mineral elements such as potassium, calcium and zinc play important roles in the maintenance of normal glucose tolerance and the release of insulin from beta cells of islets of Langerhans. Zinc present in the plant is beneficial to the prevention and treatment of diarrhoeal episode, it is also involved in the normal functioning of the immune system (Adeyeye and Otokiti, 1999).

Table 3 showed the presence of secondary metabolites such as alkaloids, saponins, tannins, glycosides, and phytate in the plant leaves may contribute to their medicinal value. Some of these compounds are well documented to exhibit hypoglycaemic activity in animals. These compounds are known to be biologically active and therefore aid their antimicrobial activities. These secondary metabolites exert antimicrobial activity through different mechanisms. Bakare et al, 2010 reported that tannins are known to react with proteins to provide the typical tanning effect which is important for the treatment of inflamed or ulcerated tissues. It was also reported that tannins are used for treating disorders such as diarrhoea and dysentery. These observations, therefore, support the use of the leaves in curing some ailments. The presence of saponins supports the fact that the leaf has cytotoxic effects such 
as permeabilization of the intestine as saponins are cytotoxic, (Bakare et al 2010). It also gives the leaves a bitter taste. Alkaloids are the most efficient therapeutically significant plant substance. They show marked physiological effects when administered to animals. The presence of these secondary metabolites in the leaves has justified the claim by the local communities in Auchi and environs for the use of this plant in the treatment of various ailments.

\section{Conclusion}

The result obtained in this study showed that the powder of bitter melon plant contains an appreciable amount of nutrients and phytochemicals. These will be good for processing bitter gourd incorporated products which can serve as successful dietetic products for subjects with disorders viz. obesity, diabetes, cardiovascular problems and general health problems.

\section{Recommendations}

i More researches should be carried out to reveal more chemical constituents of the plant

ii Further studies on the food value of the bitter melon should be investigated

iii At the advanced stage of this research, value-added food should be produced from the processed bitter melon powder

iv Based on the sugar-regulating effect of the bitter melon, it is highly recommended for diabetic patients

$\mathrm{v}$ Traditional medicine practitioners should be given enlightenment on the use of bitter melon

\section{Acknowledgement}

The authors are thankful to TETfund for providing this Institution Based Research (IBR) grant to facilitating this research. This indeed has allowed us to contribute our quota to the nation-building in term of food production and development. Thank you so much.

\section{References}

Adeyeye, E., Otokiti, M. K. O. (1999). Proximate composition and some nutritional valuable minerals of two varieties of Capsicum annum (Bell and cherry peppers). Discovery and. Innovation, 11: 75-81.

Ahmad, D., Syed, A., Abdus, S and Busra, I. (2011). Development of functional and dietetic beverage from bitter gourd. Internet Journal of Food Safety 13: 355 - 360

AOAC (2000). Official methods of analysis. Association of Official Analytical Chemists, $22^{\text {nd }} \quad$ Edition, Washington D.C, pp. 3560.

Bagchi, I. (2005). "Food for thought: Green 'karela' for Red China". Times of India (adapted from wikipedia)http://en.wikipedia.org/w/index.php?title=Momordica charantia\&oldid=63952434.

Bakare, R. I, Magbagbeola, O. A., Akinwande, A. I. and Okunowo O. W (2010) Nutritional and chemical evaluation of Momordica Charantia, Journal of Medicinal Plants Resources 4(21): 2189-2193,

Deepa, J. (2015). Development of Value Added Products from Bitter Gourd. MSc Thesis. University Agricultural Sciences. Bengaluru.

Egbon, E. E, Jimah, A and Okojie. V. U. (2015). Proximate And Essential Nutrient Compositions Of Momordica Charantia Plant. Cancer Biology. 5(3) $29-33$

Egbon, E E and Jimah, A (2015) Phytochemical Evaluation Of Selected Nigerian Medicinal Plants. Cancer Biology. 5(3) $35-37$

Food and Agriculture Organization (FAO) (2013). The United Nations Statistics online http://faostat.fao.org.

Harinantenaina L, Tanaka M, Takaoka S, Oda M, Mogami O, Uchida M, Asakawa Y. (2006). Momordica charantia constituents and antidiabetic screening of the isolated major compounds. Chemical and Pharmaceutical Bulletin 54: 1017-1021.

Ihekoronye, A. J. and Ngoddy. P. O. (1985). Integrated Food Science and Technology for the Tropics. $1^{\text {st }}$ Edition, Macmillan Publishers Ltd

Murakami T, Emoto A, Matsuda H, Yoshikawa M. (2001). Medicinal foodstuffs. Chemical and Pharmaceutical Bulletin 49: 54-63.

Myojin, H., Singh, T. K. and Alkesh, (2008). Studies on processing and development from bottle gourd. Indian Journal of Nutrition.Dietetics .45: 371-378.

Odetola, A. A., Akojenu, S. M. (2000). Antidiarrhoeal and gastro-intestinal potentials of the aqueous extract of Phyllanthus amarus (Euphorbiaceae). African Journal of Medical Sciences. 29: 119-122.

Sofowora, A. (2006). Medicinal Plants and Traditional Medicine in Africa. Ibadan, $2^{\text {nd }}$ Edition, Spectrum Books Ltd., Nigeria. pp. 151-153, 209-214

Anonymous (2020). Karela (Bitter melon) for Diabetes Management. Jumia online marketing company. www.jumia.com.ng 